\title{
Histopathology of $S$. tanaceti infection in pyrethrum leaf lamina
}

\author{
M. A. H. B. Bhuiyan ${ }^{1}$ T Groom ${ }^{2}$ M. E. Nicolas ${ }^{1}$ P. W. J. Taylor ${ }^{*}$ \\ ${ }^{1}$ Faculty of Veterinary and Agricultural Sciences, The University of Melbourne, Parkville, \\ Victoria-3010 \\ ${ }^{2}$ Botanical Resources Australia (BRA)-Agricultural Services Pty. Ltd. \\ *Email: paulwjt@unimelb.edu.au
}

\begin{abstract}
:
The infection process and life cycle of $S$. tanaceti in leaf lamina of pyrethrum plants was investigated using histopathology. Conidia attached firmly to the leaf surface before the infection hyphae penetrated directly into the epidermal cells of the leaf without forming appressoria. The maximum germination of conidia on leaf surface was $85 \%$ at 54 HAI. Infection hyphae infected the epidermal and palisade parenchyma cells through the middle lamella. Brown lesions on the leaf were a result of infected necrotic epidermal cells. Extensive colonization through both intra- and intercellular hyphae along with pycnidia formation caused enormous damage to the infected cells at 12 DAI. Unlike the quadruple stain, both single and dual stains had very limited ability to visualise infection structures. These results have provided a better understanding of the physical interaction between the pathogen and the pyrethrum leaf tissues and will help to elucidate the complete disease cycle of $S$. tanaceti on pyrethrum plant.
\end{abstract}

Key words: histopathology, microtome section, pyrethrum, ray blight, staining, S. tanaceti 


\section{Introduction:}

Pyrethrum, Tanacetum cinerariifolium (Trevir.) Schultz-Bip., is a perennial plant which belongs to the family Asteraceae and is widely used for the production of natural insecticide pyrethrins (Hitmi et al. 2000). In Australia, two thirds of world production of pyrethrum is grown commercially in northern Tasmania and around Ballarat in Victoria (Pethybridge et al. 2013). Ray blight (Stagonosporopsis tanaceti; Vaghefi et al. 2012) is one of the most important diseases of pyrethrum which produces typical necrotic symptoms on leaf margins, shoots and developing buds in spring (Pethybridge et al. 2008). Moreover, shepherd crook symptoms are produced on the flower stems with clear constriction and delineation between the necrotic peduncle and the remainder of the healthy stem. The common means of reproduction of $S$. tanaceti is through pycnidia while the sexual stage is unknown in Australia (Vaghefi et al. 2012). Although necrotic lesions were reported in pyrethrum leaves by $S$. tanaceti (Pethybridge and Wilson 1998; Pethybridge et al. 2008), a detail histopathological study of tissue infection in relation to the phenotypic symptoms on leaf surface and life cycle of the pathogen have not been documented. Considering the significance of this disease, a better understanding of the host-pathogen interaction of $S$. tanaceti in the tissues of pyrethrum is important for the implementation of integrated disease control methods.

Various techniques have been used to study the infection events of pathogenic fungi in plants. Light microscopy and single staining have been used to study the infection events on the leaf surface of hosts (Ranathunge et al. 2012; Roustaee et al. 2000). Although dual stain combinations like safranin and aniline blue/fast green (Patton and Spear 1989) or safranin and fast green (Ribichich et al. 2000) have been used to study the colonization of host tissue by various fungal pathogens, the structural and chemical changes of infected 
plant cells were not clear. However, Johansen quadruple stain (Johansen 1940) combinations have been used to study the events of infection in paraffin embedded plant tissues. This could differentiate invading fungal mycelia from the cutin, lignin, suberin and cellulose in cell walls and cell organelles, like plastids and nuclei, with contrasting colour and was used to study the infection and colonisation of wheat by the crown rot pathogen Fusarium pseudograminearum (Taylor and Burgess 1983). Besides light microscopy, both scanning electron microscopy (SEM) and green fluorescent protein (GFP) transformed fungi have been used to investigate the interaction of fungi in plant tissue. However, more advanced microscopy and molecular techniques are not practical to use on a routine basis (Liberato et al. 2005) which is time consuming and limited to a certain number of fungal strains (Knight and Sutherland 2011).

Therefore, the aim of this study was to use light microscopy and histopathology to determine the infection process and life cycle of $S$. tanaceti infection in pyrethrum leaves.

\section{Materials and methods}

\section{Fungal isolate and preparation of inoculum}

S. tanaceti isolate (Tas-1) was provided by Botanical Resources Australia (BRA) which was cultured on Potato dextrose agar (PDA; Difco, USA). For sporulation, specialized V8 medium was used followed by incubation for $2-3$-weeks at $25{ }^{\circ} \mathrm{C}$ with a $12 \mathrm{~h}$ photoperiod until formation of brown coloured pycnidia. Pycniospores generated from these pycnidia were hyaline ellipsoid to oblong with individual spore size between $7-9 \times 3-3.5 \mu \mathrm{m}$ (Vaghefi 2012). Conidia were then harvested by gently scrapping the surface of cultures 
using a sterile bent glass rod with $5 \mathrm{~mL}$ sterile distilled water (SDW). The suspension was then filtered through three layers of muslin cloth. Spore concentration was measured using a haemocytometer and adjusted to $10^{6}$ spores/mL with SDW. Tween $20(0.05 \%)$ was added as a surfactant to the spore suspension.

\section{Germination of conidia and penetration by germinated hyphae in pyrethrum leaves}

For the study of the mechanism of penetration on leaf surfaces, detached leaf laminas were collected from healthy 4-week-old pyrethrum cultivar BR1. Sixty leaf laminas were surface sterilized with $1 \%$ sodium hypochlorite for $2 \mathrm{~min}$ and then twice washed in sterile distilled water. Thirty leaf laminas were inoculated by spraying with $10^{6}$ spores/ $\mathrm{mL}$ spore suspension on both abaxial and adaxial surface. The other 30 leaf laminas were sprayed with sterile distilled water as controls. Each leaf lamina was considered as a replicate. Both inoculated and control replicates were placed separately into petri-dish with moistened sterile filter paper and incubated at $25{ }^{\circ} \mathrm{C}$ at $12 \mathrm{~h}$ photoperiod. Leaf laminas were sampled at $6,12,24,30,48$ and $54 \mathrm{~h}$ after inoculation (HAI) for microscopic studies and 5-replicates from each of inoculated and control were sampled at each time interval. Germination data were subjected to analysis of variance (ANOVA) using Minitab and means of each time after inoculation were compared using the Least Significance Differences (LSDs) at $P<0.05$ using Microsoft Excel. A modified fixing and clearing technique was used to prepare the sample (Johansen 1940). Briefly, 4, 1-cm² inoculated and control leaf tissue from each replicate at each time interval was cut using a sterile scalpel. These tissues were then processed for fixation, clearing and staining by using the steps described in Table 1. 
Table 1 Fixation, clearing and staining of pyrethrum leaf lamina

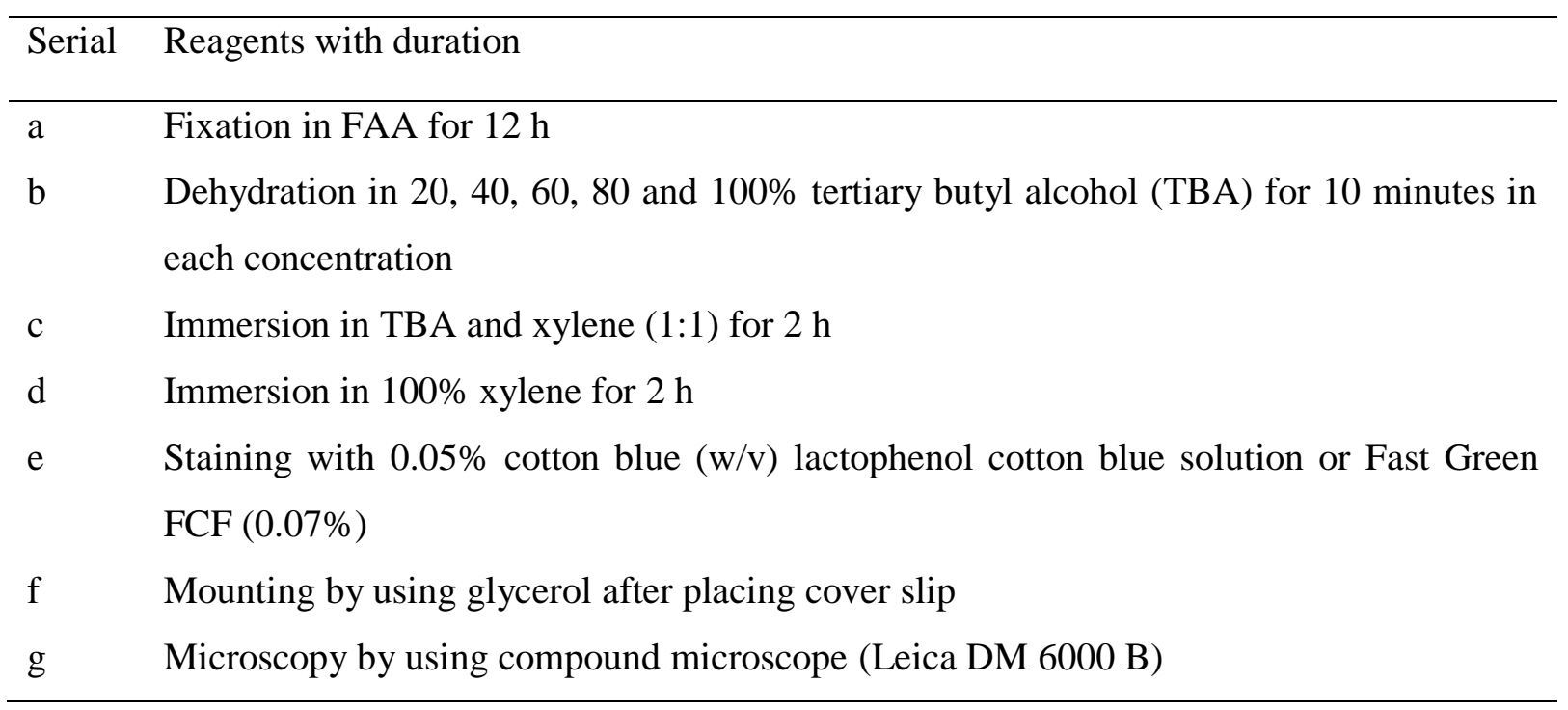

Counting of germinated spores from each replicate at each time interval was performed by selecting 100 conidia randomly at $200 \times$ magnification. A conidium was considered as germinated when the germ tube length reached half of the size of the conidium. The percent germination of spores from all the replicates was recorded at each time interval. Also, observations were made on whether the germ tube formed any specialized structures or penetrated directly into the host tissue and it's affinity for penetration through stomata and natural openings from 6 to $54 \mathrm{HAI}$.

For the histopathological study of the mechanism of penetration in leaf tissues, another 4 tissue pieces $\left(1-\mathrm{cm}^{2}\right)$ were taken randomly from the above detached inoculated and control leaves each time after inoculation followed by fixation, dehydration and tissue clearing following the steps in Table-1. Tissue samples were then embedded in paraffin and sectioned using a Leica rotary microtome as described in Table 2. Sections were stained using modified quadruple, dual and single stains as described in Table 3 , to visualise infection structures. 
Table 2 Processing of tissues for differential stains

\begin{tabular}{|c|c|c|}
\hline Serial & Steps & Procedure with instruments used \\
\hline $\mathrm{h}$ & Embedding of the tissue with paraffin & $\begin{array}{l}\text { Paraffin poured from the paraffin } \\
\text { reservoir }\left(60{ }^{\circ} \mathrm{C}\right) \text { (Leica EG } 1150 \mathrm{H} \text { ) } \\
\text { using a metal mold (Leica Parafree } \\
\text { stainless steel base mold } 25 \times 25 \mathrm{~mm} \text { ) } \\
\text { fitted with a plastic cassette (Leica white } \\
\text { bulk MC bases) }\end{array}$ \\
\hline $\mathrm{i}$ & Solidification of the paraffin & $\begin{array}{l}\text { Solidified on a cold stage }\left(-5^{\circ} \mathrm{C}\right) \text { (Leica } \\
\text { EG } 1150 \mathrm{C}) \text { for } 20 \text { minutes }\end{array}$ \\
\hline $\mathrm{j}$ & Trimming of the block & $\begin{array}{l}\text { Sharp knife was used to trim the blocks to } \\
\text { make ready for microtome sectioning }\end{array}$ \\
\hline $\mathrm{k}$ & Labelling of the block & Paraffin blocks were labelled with pencil. \\
\hline 1 & Microtome section & $\begin{array}{l}\text { Multiple ribbons of } 7-8 \mu \mathrm{M} \text { thickness } \\
\text { were performed using rotary microtome } \\
\text { (Leica RM } 2125 \text { RTS) and floated on } \\
\text { water bath. }\end{array}$ \\
\hline $\mathrm{m}$ & Slide preparation and labelling & $\begin{array}{l}4 \text { ribbons were placed in each slide (Leica } \\
\text { Surgipath Snowcoat microslides } 2.5 \mathrm{~cm} \times \\
7.0 \mathrm{~cm} \times 1.0 \mathrm{~cm} \text { ). Slides were labelled as } \\
\text { 'I' for inoculated and 'C' for control using } \\
\text { pencil. }\end{array}$ \\
\hline $\mathrm{n}$ & Incubation of slides & $\begin{array}{l}\text { Slides were incubated on hot plate at } 60 \\
{ }^{\circ} \mathrm{C} \text { for } 1 \mathrm{~h} \text {. }\end{array}$ \\
\hline o & Dewaxing & $\begin{array}{l}\text { Immersion of slides in absolute xylene for } \\
5 \mathrm{~min}\end{array}$ \\
\hline $\mathrm{p}$ & Removal of xylene & $\begin{array}{l}2 \text { ethanol treatments (100 and } 70 \% \\
\text { concentrations) were used by dipping the } \\
\text { slides for } 5 \mathrm{~min} \text { in each }\end{array}$ \\
\hline
\end{tabular}

Slides were then stained using the compositions in Table 3. 
Table 3 Composition of differential stains

Quadruple stain (modified from Johansen Dual stain (modified from Single stain

Ribichich et al. 2000) (Ranathunge et al.

2012)

Immersed in Safranin $\mathrm{O}$ for $2 \mathrm{~h}$ then rinsed Safranin $\mathrm{O}$ was used as a Lactophenol cotton

for 2-3 times using distilled water followed primary stain for $2 \mathrm{~h}$ blue solution was

by $5 \mathrm{~min}$ immersed in crystal violet then followed by rinses with used for $10 \mathrm{~min}$

washed with distilled water for twice. Then sterile distilled water. followed by 2-3

extra stains were removed by using EMT Then extra stains were rinses in sterile water.

for $15 \mathrm{~min}$. Then staining for $5 \mathrm{~min}$ in Fast removed by using EMT

Green FCF solution followed by removal for $15 \mathrm{~min}$. Then Fast

of extra stain by using EMT for $15 \mathrm{sec}$. Green FCF solution was

Final staining was done by using Orange $G$ used for $10 \mathrm{~min}$ as a

for $3 \mathrm{~min}$. Afterwards; extra stains were counter stain. Extra stain

removed by using two changes of CME was removed by using

and CMX for $15 \mathrm{sec}$ in each. Final step EMT and CME

before mounting with immersion of the respectively for $15 \mathrm{sec}$.

slides in xylene for $5 \mathrm{~min}$.

EMT: Ethanol (95\%): methyl cello solve: tert-butanol (1:1:1), CME: Clove oil: methyl cell solve: ethanol (95\%) (1:1:1), CMX: Clove oil: methyl cello solve: xylene (1:1:1)

After staining, all the slides were immersed in xylene for 5 min followed by mounting with Leica Surgipath Micromount and placement of glass cover slips over the sample.

\section{Infection, colonization and formation of pycnidia in pyrethrum leaves}

For the study of phenotypical symptom expression between 1 and 12 DAI, a further 30 leaf laminas were selected from healthy 4-week-old pyrethrum plants (cultivar BR1). Twenty leaf laminas were inoculated with $S$. tanaceti at a concentration of $10^{6} \mathrm{spores} / \mathrm{mL}$ following the same process of surface sterilization, inoculation and incubation as described above. Another 10 leaf laminas were used as a control and were sprayed with 
SDW. 5 replicates of each of inoculated and control leaflets were kept in a sterile moistened filter paper placed in a $90 \mathrm{~mm}$ petri plates and incubated at $25{ }^{\circ} \mathrm{C}$ temperature in $12 \mathrm{~h}$ photoperiod. Each leaf lamina was treated as a replicate. Progressive lesion development and pycnidia formation was assessed on both sides of leaves using the dissecting microscope (Leica M 205 FA). Lesion size was measured using the Leica software.

For histopathological study of infection and colonization, 4 tissue pieces $\left(1 \mathrm{~cm}^{2}\right)$ were taken randomly from the detached inoculated and control leaves by cutting at the junction of the necrotic lesion of infected leaf and any point of the control leaf lamina respectively at 3 and 12 DAI using a sterile scalpel. Then $0.5 \mathrm{~cm}^{2}$ piece was used for culturing in water agar (1\%) for 3 days followed by subculturing in V8 media to confirm the presence of S. tanaceti using the taxonomy of conidiomata and pycnidia (Vaghefi 2012). The other $0.5 \mathrm{~cm}^{2}$ tissue piece was processed and labelled for histopathology. According to the results on V8 medium, the corresponding tissue in the paraffin blocks were subsequently labelled as Infected (IL) Control leaf $(\mathrm{Cl})$ were processed for histopathology. Microtome sections, slide preparation and use of differential stains were followed as mentioned in Tables 2 and 3.

All plant tissues on prepared slides were observed under the light microscope (Leica DM $6000 \mathrm{~B})$ and the images were taken using a Leica DFC $450 \mathrm{C}$ camera. 


\section{Results}

\section{Germination of conidia and penetration by germinated hyphae in pyrethrum leaves}

Germination of conidia started at 12 HAI and significantly increased over time. The germination percentage of conidia was $11,29,41,60$ and $85 \%$ at $12,24,30,48$ and 54 HAI respectively on adaxial leaf surface (Fig. 1). No specialized penetration structures occurred and the infection hyphae had no affinity towards the natural openings like stomata (Fig. 2 a) in each observation up to 54 HAI. Both lactophenol cotton blue and Fast Green FCF (0.07\%) were effective to visualize the germinated spores on cleared leaf surface.

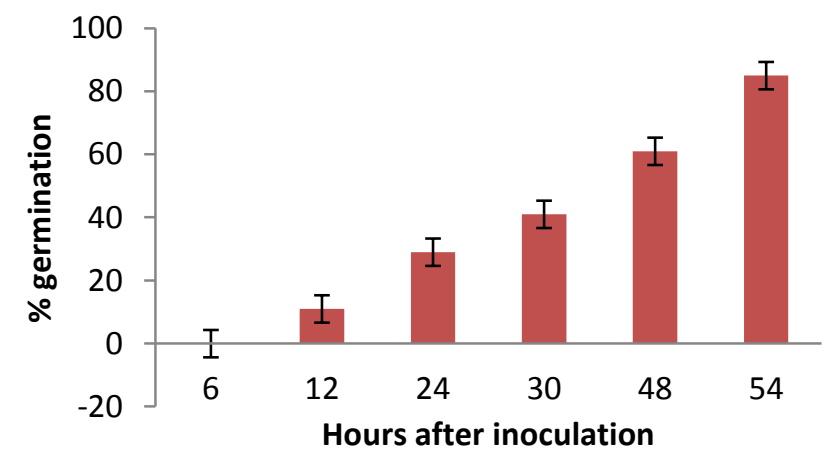

Fig. 1 Percent germination of $S$. tanaceti conidia over time on adaxial leaf surface of pyrethrum (Each bar denotes LSD value at significance level $P<0.05$, there were 5 replications for each time observation) 


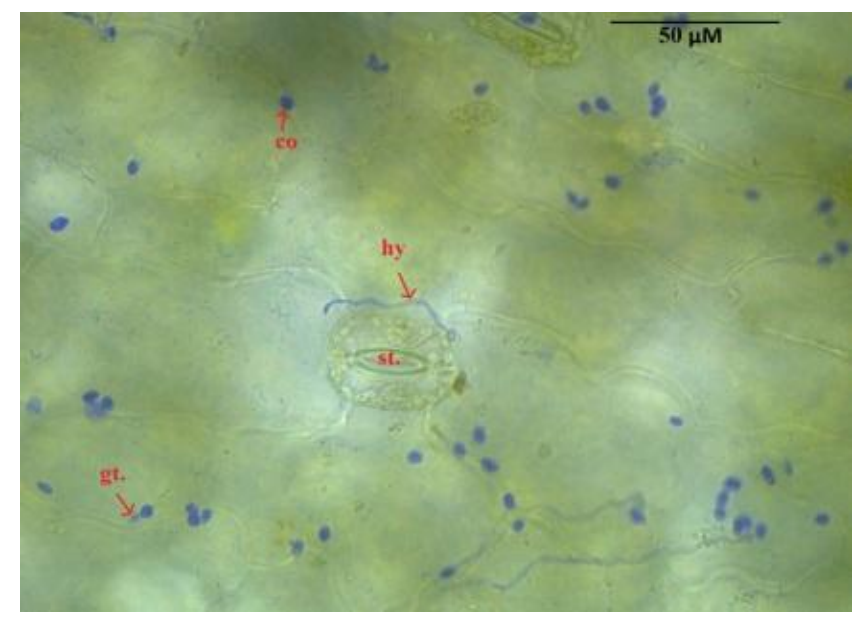

Fig. 2 a) infection hypha (hy) or germ tube (gt) from the conidia (co) had no affinity towards stomata (st) at 12 HAI.

Using quadruple stain it was observed that the germ tubes initiated from the firmly attached conidia penetrated directly through the upper layer of adaxial epidermis at 12 HAI. Firm attachment was represented as a slight depression at the point of attachment of conidium on host surface (Fig. 3 a). Over time, infection hyphae from the adaxial epidermis moved horizontally through the epidermis by invading the middle lamella of epidermal cells (Fig. 3 b) or moved vertically through the middle lamella in between two mesophyll parenchyma cells (Fig. 3 c) or directly penetrated into the mesophyll tissues (Fig. 3 d) at 54 HAI. However, both single and dual stain techniques were unsuccessful to aid visualisation of any infection structures on infected leaf surface at 12 and 54 HAI.
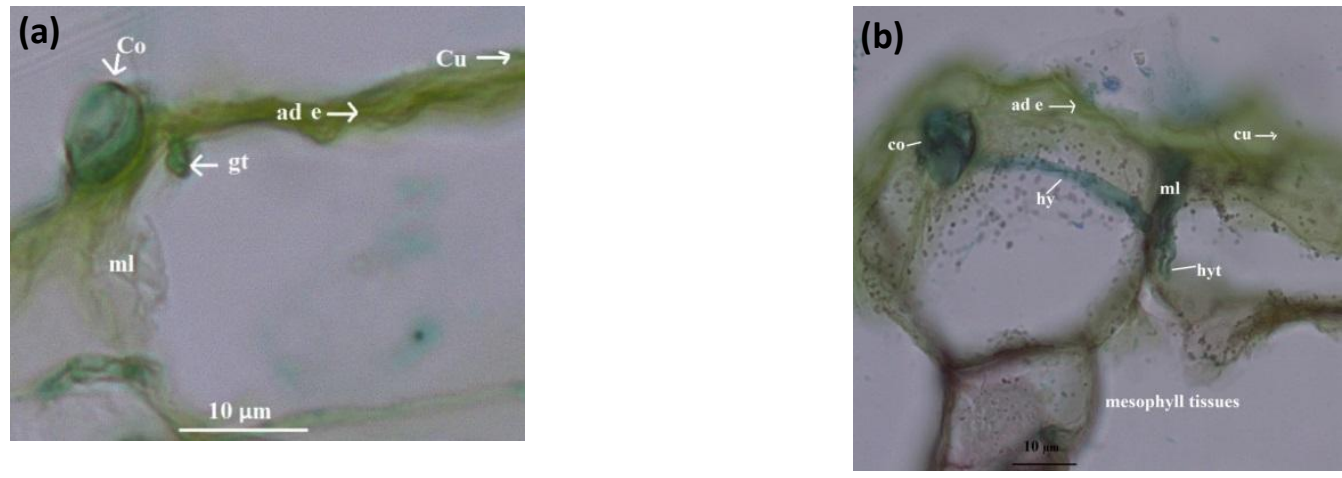

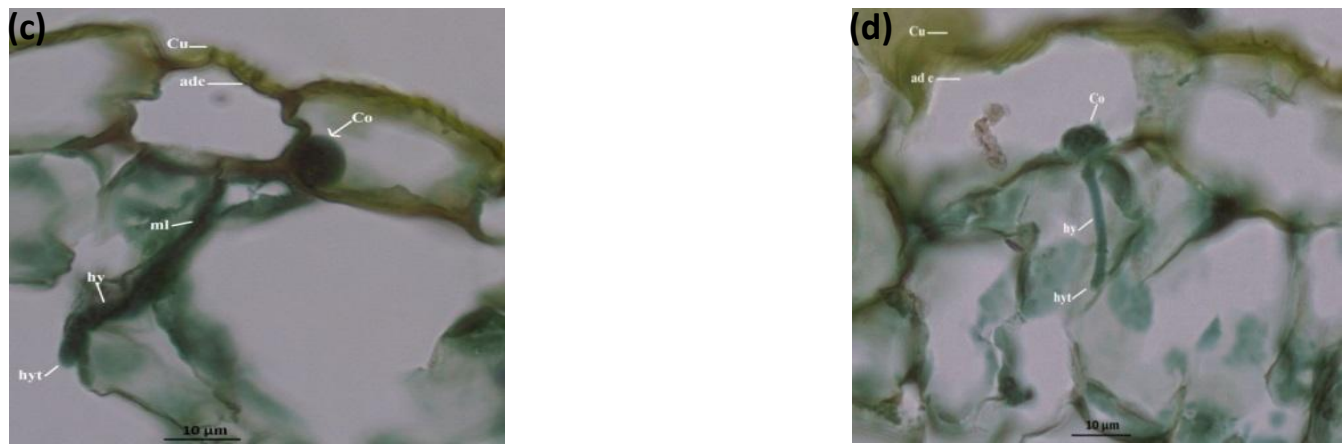

Fig. 3 Penetration of infection hyphae in pyrethrum leaves by $S$. tanaceti using quadruple stain. a) firm attachment of conidium (co) at the point of attachment on host surface, germ tube (gt) penetrated directly through the cuticle (cu) and adaxial epidermis (ad e); b) infection hypha (hy) extended horizontally through the middle lamella $(\mathrm{ml})$ of two epidermal cells; c) infection hypha (hy) from the germinated conidium (co) infected horizontally through the middle lamella (ml) of two adjacent mesophyll parenchyma cells; d) infection hypha (hy) penetrated directly from the adaxial epidermis (ad e) to the mesophyll tissues.

\section{Infection, colonization and formation of pycnidia on leaf tissues}

Pin point necrotic lesions developed sparsely on the adaxial surface of inoculated leaves at 1 DAI (Fig. 4 a) and developed into distinct brown discoloured lesions $(300 \times 550$ $\mu \mathrm{M}^{2}$ ) on adaxial leaf surface 3 DAI (Fig. 4 b). Over time, some of the lesions coalesced to form black to deep brown lesions $\left(3.0 \times 3.5 \mathrm{~mm}^{2}\right)$ particularly at the tip of the leaves at 5 6 DAI which were more obvious on the adaxial surface than abaxial surface (Fig. 4 c). Pycnidia formed at $9 \mathrm{DAI}$ and the ostiole of the pycnidia was visible at $12 \mathrm{DAI}$. Almost the entire leaf lamina was covered by the pycnidia which changed the leaf lamina colour to brown. Distribution of the pycnidia was more in the adaxial leaf surface than abaxial leaf surface (Fig. 4 d). Control leaf samples showed no symptoms. 

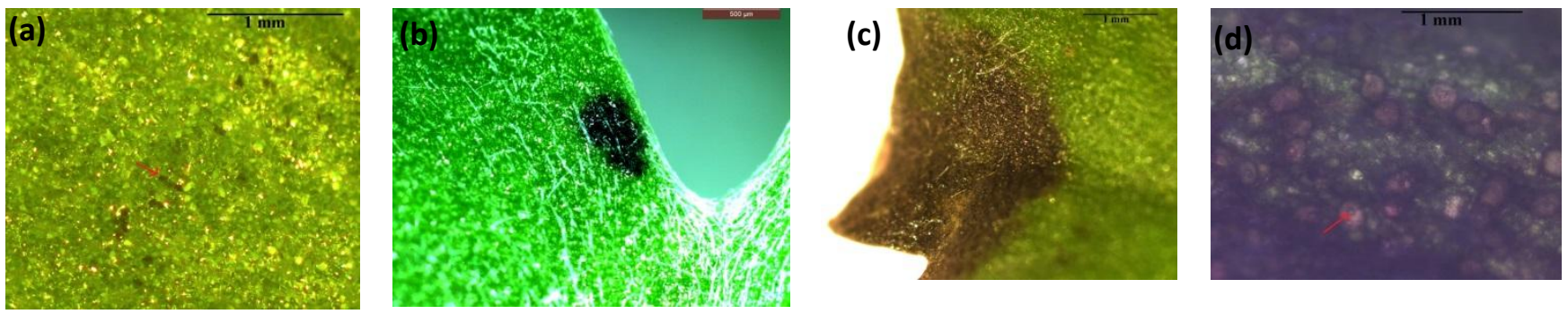

Fig. 4 a) pin point necrotic lesions (red arrow) on adaxial leaf surface at 1 DAI; b) typical necrotic lesion on adaxial leaf surface at $3 \mathrm{DAI}$; c) extended necrotic lesion at the tip of the leaf lamina at $5 \mathrm{DAI}$; d) pycnidia with ostiole (red arrow) on the adaxial leaf surface at 12 DAI.

Using the quadruple stains at 3 DAI, the colonized leaf tissue had a brown discolouration in comparison to the adjacent non colonized cells (Fig. 5 a-b) and adaxial epidermal tissues of control leaf (Fig. 5 c). Brown discolouration was extended in the same direction of hyphal movement (Fig. 5 b). During this time, hyphae penetrated only into the palisade parenchyma through the middle lamella. Some deformation was observed in and around the colonized host cells. Moreover, no colonization was observed in the spongy parenchyma and xylem vessels of vascular bundle (Fig. 5 a).

In contrast, both palisade and spongy parenchyma cells of mesophyll tissue were severely affected at 12 DAI. Both inter- and intra-cellular colonization was seen in the mesophyll tissues. The middle lamella in between the infected mesophyll cells was not only deformed but in some cases degraded. Cellular materials inside the infected host cells were either dissolved or disappeared. Infected host cells had a brown discolouration with thick cell walls with degradation (Fig. 5 d). Deposition of reddish coloured extra-cellular materials was observed in the infected host cells which also caused cell wall thickening (Fig. 5 e). During this period of infection, S. tanaceti formed pycnidia and colonized mostly on both adaxial and abaxial epidermis at 12 DAI. However, frequency of the pycnidia (2-3 per $2 \mathrm{~mm}$ infected leaf area) was more in the adaxial surface than abaxial 
leaf surface ( 1 per $2 \mathrm{~mm}$ infected leaf area). No pycnidia formed on the stomatal region and mesophyll tissues. Opening of the pycnidia was outward. Host tissues around the pycnidium were brown discoloured, thick walled and degraded (Fig. 5 f). Meanwhile, cell walls of control mesophyll tissues after 12 days were intact and green in colour with green coloured cellular materials (Fig. 5 g).

Pycnidia also were visualised as a deep blue colour at 12 DAI after staining with single stain of lactophenol cotton blue solution. However, no other intra- and inter-cellular colonization and host responses were recognized with this staining method (Fig. $5 \mathrm{~h}$ ). Meanwhile, Safranin O and Fast Green FCF were used as a primary stain and a counter stain respectively enabled to be visualised hyphae as green colour, pycnidia as pinkish green to brown colour, infected host cells as light green to brown colour with extracellular deposits as pinkish green to brown colour (Fig. 5 i). However, these were not as clear as when stained with the quadruple stain method at 12 DAI.
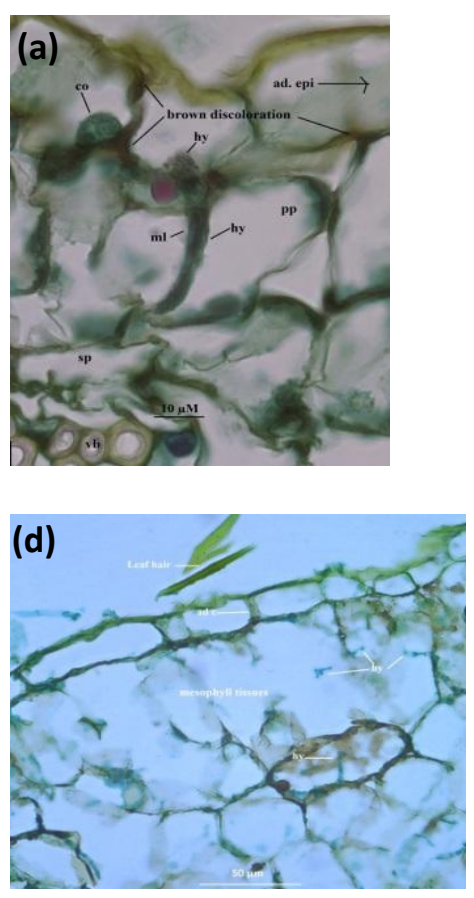
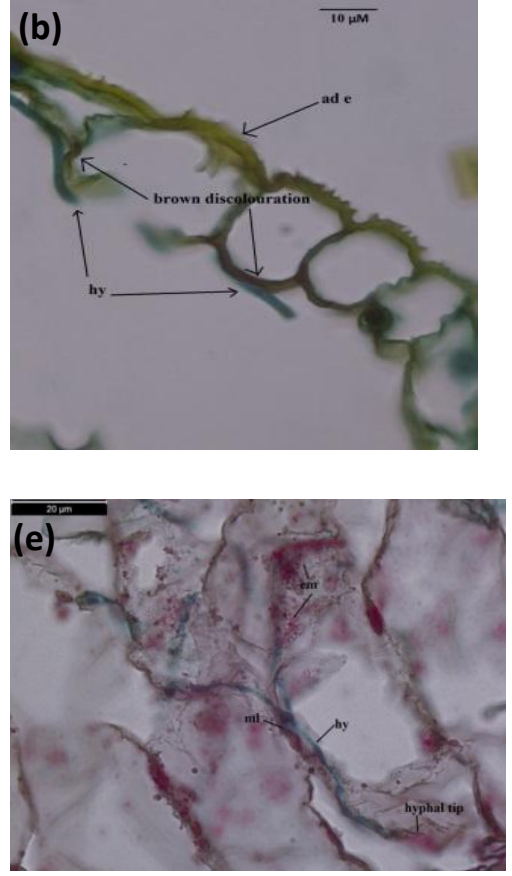
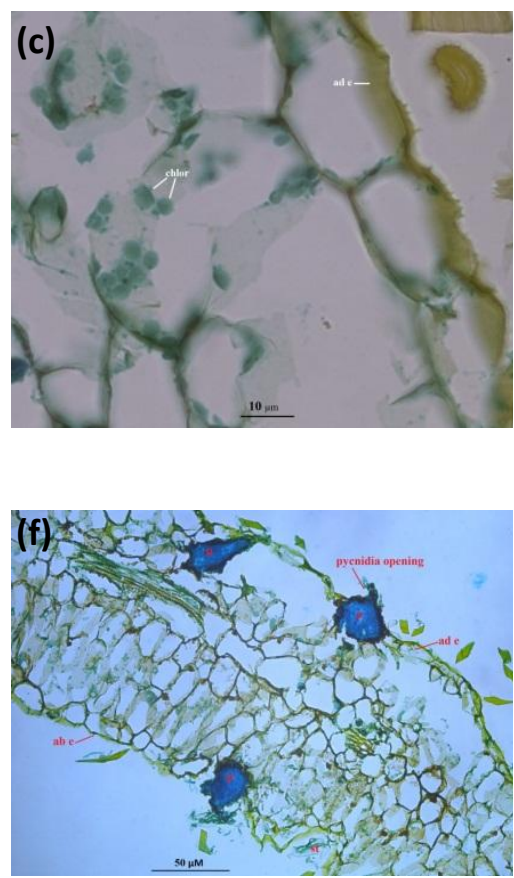

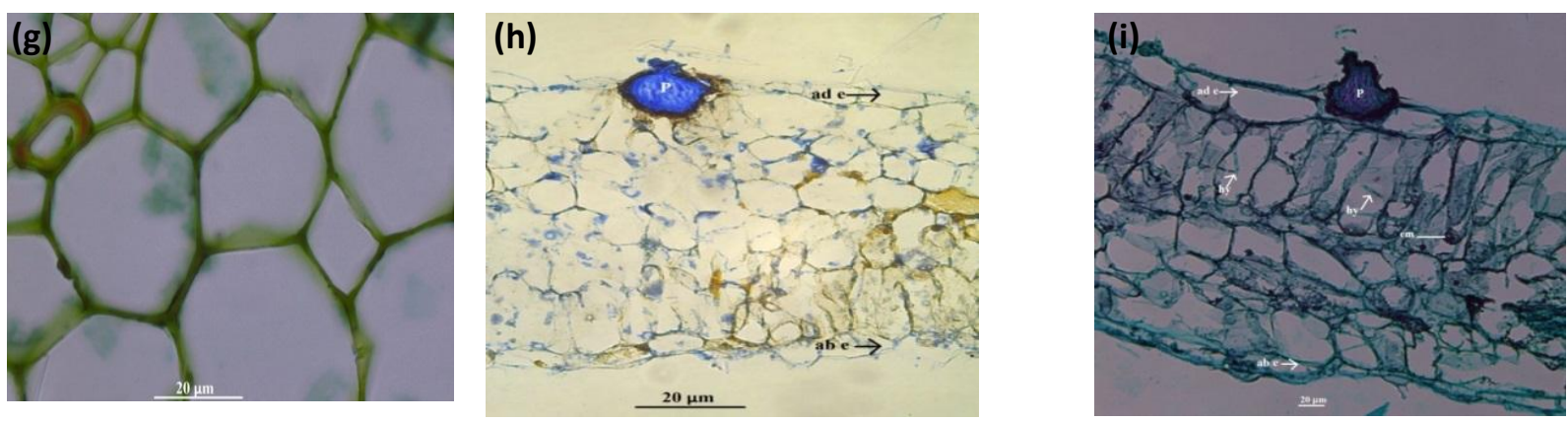

Fig. 5 a) hyphae (hy) penetrated directly through the middle lamella (ml) in between two palisade parenchyma (pp) cells with brown discolouration on colonized adaxial epidermis (ad e) and no colonization in spongy parenchyma (sp) and xylem vessels of vascular bundle (vb); b) adaxial epidermal ( $\mathrm{ad}$ e) cell became brown in colour at the point where infection hypha (hy) attached which was extended in the same direction of hyphal movement; c) healthy epidermal and mesophyll tissues were bright in colour and cell organelles were unaffected; d) degradation of colonized palisade and spongy mesophyll tissues with brown discolouration of infected cell walls and intra-cellular colonization of hyphae (hy) caused degradation of spongy parenchyma cells; $\mathbf{e}$ ) invasion of hyphae (hy) through the middle lamella (ml) of mesophyll tissues caused deposition of some reddish extra-cellular materials $(\mathrm{em})$ in and around the infected cells; $\mathbf{f})$ pycnida $(\mathrm{p})$ developed on both the adaxial epidermis ( $\mathrm{ad}$ e) and abaxial epidermis ( $\mathrm{ab}$ e), no pycnidia formed on stomata (st) and cell walls of infected tissues were brown discoloured at $12 \mathrm{DAI} ; \mathbf{g}$ ) cell walls of mesophyll tissues of control leaves were bright yellowish green in colour; $\mathbf{h}$ ) pycnidium (p) on the adaxial epidermis was shown blue colour when stained with lactophenol cotton blue, no other infective structures were observed; i) mycelia stained green, pycnidium (p) pinkish green to brown colour and some extracellular material (em) as pink to brown colour when used dual stain (Safranin $\mathrm{O}$ and Fast Green FCF).

\section{Discussion}

Germination of conidia on leaf surface increased with an increase in the incubation period for just over 2 days. Before germination, conidia were attached firmly on the surface of the leaf which was marked by a slight depression in the cuticle of leaf. Attachment of conidia has been shown to be essential for the successful establishment of pathogenesis of Magnaporthe grisea (Tucker and Talbot 2001) where spores were firmly anchored to the 
host surface (Nicole and Gianinazzi-Pearson 1996). Depression on the host surface at the point of conidia attachment was reported for $P$. macdonaldii on sunflower cotyledon surface (Roustaee et al. 2000). The germ tube had no affinity towards natural openings such as stomata nor formed an appressoria during the incubation period. This was also found for spores of similar kinds of fungal pathogens such as Leptophaeria maculans in which hyphae directly penetrated the surface of canola leaf lamina (Brassica napus) without forming appressoria. In contrast, hyphae of L. maculans on canola leaf lamina (Hammond et al. 1985; Idnurm and Howlett 2002) and Phomopsis phaseoli on soybean seedlings (Kulik 1988) also entered through the stomata as well as direct penetration.

Histopathology using quadruple stain showed that the infection hyphae penetrated directly into the epidermal cells and then further moved toward the mesophyll tissues inter-cellularly. Direct penetration has commonly been reported in related fungi like Phoma medicaginis in alfalfa leaf (Castell-Miller et al. 2007), P. clematidina on clematis (Clematis spp.) leaf surface (Van de Graaf et al. 2002) and S. nodorum in wheat leaf (Solomon et al. 2006). Direct penetration was mentioned by Roustaee et al. (2000) that at the point of conidia attachment of $P$. macdonaldii on sunflower cotyledon surface, germ tubes formed infection pegs which perforated the host cuticle through exerting mechanical pressure.

Phenotypic expression of initial pin point brown necrotic lesions appeared on leaf surface at $1 \mathrm{DAI}$ and the lesions extended alongside the margin which completely covered the entire leaf lamina within 9-12 DAI. Fully matured pycnidia were almost evenly distributed on the infected necrotic leaves at 12 DAI. Likewise in histopathology at 3 DAI brown pigmented infected epidermal cells at the colonized area were distinct in comparison to the healthy cells away from the colonized or uninfected control epidermal 
leaf tissues. The brown discolouration of the infected cells by S. tanaceti might have been caused by the release of some toxins at the infection site, because some related fungi like Phoma and Ascochyta species (Pedras and Biesenthal 2000; Fogliano et al. 1998; Idnurm and Howlett 2002) have been shown to release toxins at the site of infection and cause brown discolouration. Similar brown pigmentation was also reported in the lesion area of L. maculans infected canola leaves (Sexton and Howlett 2001).

Intercellular colonization by hyphae of $S$. tanaceti occurred within the palisade parenchyma without any obvious damage at 3 DAI which was in full agreement with the infection nature of L. maculans in the infected leaf tissues of oilseed rape at initial stage of infection (Hammond et al.1985). But, infection hyphae ramified intra- and intercellularly within the spongy and palisade parenchyma tissues at 12 DAI. Middle lamella of parenchyma cells may have been either degraded or dissolved due to activation of cell decomposing enzymes like cyanide hydratase as reported by Sexton and Howlett (2001). Some of the infected cell walls were thickened around the middle lamella of parenchyma cells which might have indicated the deposition of lignin (Hammond and Lewis 1987; Sexton and Howlett 2001). Likewise, heavy lignification and deposition of tannin were observed in the heavily infected tissues of lodgepole pine (Pinus contorta Dougl.) seedlings after infection by either Anthracobia maurilabra, A. tristis, Geopyxis carbonaria or Gyromitra infula (Egger and Paden 1986).

The frequency of necrotic lesions and pycnidia after inoculation by $S$. tanaceti were more on the adaxial epidermis than abaxial epidermis of leaf lamina. A survey conducted in 1909 by Heald and Wolf (1911) in Texas reported similar nature of abundant brown spots and pycnidia formation on upper leaf surfaces of cultivated crops infected by Phyllosticta congesta and $P$. bumeliifolia. However, further studies are needed to explore the reason 
for higher frequency of lesions and pycnidia caused by $S$. tanaceti on the adaxial surface compared to the abaxial surface of pyrethrum leaves.

The single stain technique was found to be useful to identify the infection events on cleared leaf surface but almost ineffective in histopathological studies. Whereas, the dual stain technique, although useless in histopathology at initial stage of infection and was limited to the latter stage of infection when host cellular materials were almost degraded and pycnidia formed. In contrast, the quadruple stain was informative for histopathological analysis of infected tissues at any stages of infection caused by $S$. tanaceti in pyrethrum leaves. This technique could be used as an alternate to some costly tissue staining processes such as GFP and advanced microscopy such as SEM or Transmission electron microscopy (TEM). Application of the quadruple stain to study varietal resistance, infection process of $S$. tanaceti from seed to seedling and to explore the complete disease cycle of ray blight in pyrethrum is currently underway.

\section{Acknowledgements:}

This project was supported by Botanical Resources Australia (BRA)-Agricultural Services Pty. Ltd.

\section{References}

Egger KN, Paden JW (1986) Biotrophic associations between lodgepole pine seedlings and post fire ascomycetes (Pezizales) in monoxenic culture. Can J Bot 64(11):2719-2725

Fogliano V, Marchese A, Scaloni A, Ritieni A, Visconti A, Randazzo G, Graniti A (1998) Characterization of a $60 \mathrm{kDa}$ phytotoxic glycoprotein produced by Phoma tracheiphilaand its relation to malseccin. Physiol Mol Plant Pathol 53(3): 149-161 
Hammond KE, Lewis B, Musa T (1985) A systemic pathway in the infection of oilseed rape plants by Leptosphaeria maculans. Plant Pathol 34(4): 557-565

Hammond KE, Lewis BG (1987) Variation in stem infections caused by aggressive and nonaggressive isolates of Leptosphaeria maculans on Brassica napus var. oleifera. Plant Pathol 36(1):53-65

Heald FD, Wolf FA (1911) New species of Texas fungi. Mycologia 3(1): 5-22

Hitmi A, Coudret A, Barthomeuf C (2000) The production of pyrethrins by plant cell and tissue cultures of Chrysanthemum cinerariaefolium and Tagetes species. Critical reviews in biochemistry and molecular biology 35(5):317-337

Idnurm A, Howlett BJ (2002) Isocitrate lyase is essential for pathogenicity of the fungus Leptosphaeria maculans to canola (Brassica napus). Eukaryotic Cell 1(5): 719-724

Johansen DA (1940) Plant microtechnique. New York, McGraw-Hill.

Knight NL, Sutherland MW (2011) A rapid differential staining technique for Fusarium pseudograminearum in cereal tissues during crown rot infections. Plant Pathol 60(6): $1140-1143$

Kulik M (1988) Observations by scanning electron and brightfield microscopy on the mode of penetration of soybean seedlings by Phomopsis phaseoli. Plant Dis 72:115-118

Liberato J, Barreto R, Shivas R (2005) Leaf-clearing and staining techniques for the observation of conidiophores in the Phyllactinioideae (Erysiphaceae). Australas Plant Pathol 34(3):401-404

Nicole M, Gianinazzi-Pearson V (1996) Histology, ultrastructure and molecular cytology of plant-microorganism interactions. $1^{\text {st }}$ edition, Kluwer Academic Publishers. The Netherlands.

Patton RF, Spear RN (1989) Histopathology of colonization in leaf tissue of Castilleja, Pedicularis, Phaseolus, and Ribes species by Cronartium ribicola. Phytopathology 9(5):539-547 
Pedras MSC, Biesenthal CJ (2000) Vital staining of plant cell suspension cultures: evaluation of the phytotoxic activity of the phytotoxins phomalide and destruxin B. Plant Cell Reports 19(11): 1135-1138

Pethybridge SJ, Gent DH, Groom T, Hay FS (2013) Minimizing crop damage through understanding relationships between pyrethrum phenology and ray blight disease severity. Plant Dis 97(11):1431-1437

Pethybridge SJ, Hay FS, Esker PD, Gent DH, Wilson CR, Groom T, Nutter Jr FW (2008) Diseases of pyrethrum in Tasmania: challenges and prospects for management. Plant Dis 92(9):1260-1272

Pethybridge SJ, Wilson C (1998) Confirmation of ray blight disease of pyrethrum in Australia. Australas Plant Pathol 27(1): 45-48

Ranathunge N, Mongkolporn O, Ford R, Taylor P (2012) Colletotrichum truncatum Pathosystem on Capsicum spp: infection, colonization and defence mechanisms. Australas Plant Pathol 41(5):463-473

Ribichich KF, Lopez SE, Vegetti AC (2000) Histopathological spikelet changes produced by Fusarium graminearum in susceptible and resistant wheat cultivars. Plant Dis 84(7): 794802

Roustaee A, Dechamp-Guillaume G, Gelie B, Savy C, Dargent R, Barrault G (2000) Ultrastructural studies of the mode of penetration by Phoma macdonaldii in sunflower seedlings. Phytopathology 90(8): 915-920

Sexton A, Howlett B (2001) Green fluorescent protein as a reporter in the BrassicaLeptosphaeria maculans interaction. Physiol Mol Plant Pathol 58(1):13-21

Taylor PWJ, Burgess LW (1983) Histopathology of infection and colonisation of wheat by Fusarium graminearum Group 1. Proceedings of the 4th International Congress of Plant Pathology, Melbourne. 
Tucker SL, Talbot NJ (2001) Surface attachment and pre-penetration stage development by plant pathogenic fungi. Annu Rev Phytopathol 39(1):385-417

Vaghefi N, Pethybridge S, Ford R, Nicolas M, Crous P, Taylor P (2012) Stagonosporopsis spp. associated with ray blight disease of Asteraceae. Australas Plant Pathol 41(6): 675-686

Van De Graaf P, Joseph ME, Chartier-Hollis JM, O’Neill TM (2002) Prepenetration stages in infection of clematis by Phoma clematidina. Plant Pathol 51(3):331-337 


\section{Appendix:}

\begin{tabular}{|c|c|c|}
\hline SI & Reagents/ Stain & Compositions \\
\hline 1 & V8 media & $\begin{array}{l}\text { Sterile distilled water } 271 \mathrm{~mL}, \mathrm{CaCO} 31.31 \mathrm{~g} \text {, Agar } 7 \mathrm{~g} \text { and } \mathrm{V} 8 \\
\text { juice } 78.75 \mathrm{~mL} \text { with adjusted } \mathrm{pH} \text { at } 6.25 \text {, then autoclave at } 121 \\
{ }^{\circ} \mathrm{C} \text { for } 20 \mathrm{~min} \text {. }\end{array}$ \\
\hline 2 & FAA & $\begin{array}{l}10 \% \text { formalin, } 5 \% \text { acetic acid, } 50 \% \text { ethanol and } 35 \% \text { sterile } \\
\text { water }\end{array}$ \\
\hline 3 & $\begin{array}{l}\text { Lactophenol cotton } \\
\text { blue solution }\end{array}$ & $\begin{array}{l}0.05 \% \text { cotton blue (w/v) in compositions of } 20 \% \text { ethanol, } 20 \% \\
\text { lactic acid, } 40 \% \text { glycerol and } 20 \% \text { distilled sterile water }\end{array}$ \\
\hline 4 & Safranin O & $\begin{array}{l}100 \mathrm{~mL} \text { methyl cello solve, } 50 \mathrm{~mL} \text { absolute ethanol, } 50 \mathrm{~mL} \text { DI } \\
\text { water, } 2 \mathrm{~g} \text { sodium acetate, } 4 \mathrm{~mL} 37 \% \text { formalin, } 2 \mathrm{~g} \text { Safranin O } \\
\text { powder (Sigma- S } 2255100 \mathrm{~g} \text { ). }\end{array}$ \\
\hline 5 & Fast Green FCF & $\begin{array}{l}0.25 \mathrm{~g} \text { Fast Green powder (Sigma- F } 72525 \mathrm{~g}) \text { in } 50 \mathrm{~mL}(1: 1) \\
\text { methyl cello solve: clove oil (Sigma C } 8392500 \mathrm{~mL}), 150 \mathrm{~mL} \\
\text { absolute ethanol, } 150 \mathrm{~mL} \text { tert-butanol }(100 \%) \text { and } 3.5 \mathrm{~mL} \\
\text { glacial acetic acid }\end{array}$ \\
\hline 6 & Orange $\mathrm{G}$ & $\begin{array}{l}1 \mathrm{~g} \text { Orange } \mathrm{G} \text { powder (Sigma O } 375625 \mathrm{~g} \text { ) in } 200 \mathrm{~mL} \text { methyl } \\
\text { cello solve in } 100 \mathrm{~mL} \text { absolute ethanol }\end{array}$ \\
\hline & Crystal Violet & $\begin{array}{l}1 \mathrm{~g} \text { Crystal violet powder (Sigma C-6158 100g) in } 100 \mathrm{~mL} \\
\text { sterile distilled water }\end{array}$ \\
\hline
\end{tabular}




\section{University Library}

\section{- M M I N E R VA A gateway to Melbourne's research publications}

Minerva Access is the Institutional Repository of The University of Melbourne

\section{Author/s:}

Bhuiyan, MAHB;Groom, T;Nicolas, ME;Taylor, PWJ

Title:

Histopathology of S-tanaceti infection in pyrethrum leaf lamina

\section{Date:}

2015-11-01

Citation:

Bhuiyan, M. A. H. B., Groom, T., Nicolas, M. E. \& Taylor, P. W. J. (2015). Histopathology of S-tanaceti infection in pyrethrum leaf lamina. AUSTRALASIAN PLANT PATHOLOGY, 44 (6), pp.629-636. https://doi.org/10.1007/s13313-015-0377-0.

Persistent Link:

http://hdl.handle.net/11343/283004 